\title{
Citizenship and Military Service in Italian-American Relations, 1901-1918
}

\section{By Bahar Gürsel, Bilkent University}

Conflicts over citizenship and military service became a central issue in Italian-American relations in the early twentieth century. The United States and Italy founded their concepts of citizenship on two different bases, jus soli and jus sanguinis. As a consequence of this difference and the swelling number of Italian immigrants naturalized in America, the two governments' policies about naturalization and military service collided until 1918. The Italian government's policy put Italian Americans' loyalty to the United States in jeopardy, especially for men who wished to return to Italy for business or educational purposes. Thus, the study of Italian Americans' experiences in the context of the policies of both countries illustrates a key aspect of the relationship between the United States and Italy, both in terms of social experience and public policy.

Former Italian foreign minister and prime minister Giulio Andreotti once observed that Italian migration around the world "created a consistent network of ties between Italy and the host countries, which caused Italy to take a great and continuing interest in the state of those countries and in their mutual relations."1 Beginning in the 1880 s, one of those host countries that received the highest rate of Italian immigrants was the United States, and thus the relationship between the United States and Italy entered a remarkable stage in the late nineteenth and the early twentieth centuries. The influx of Italians to American shores not only demonstrated the social, cultural, and economic distinctions between newly united Italy and the United States. It also revealed diverse and sometimes conflicting Italian and American ideas and laws about the issue of citizenship.

The early relationship between the United States and Italy began well but gradually deteriorated. Americans supported the independence of Italy during the 1848-49 revolutions and encouraged the Kingdom of Italy towards unification. After the Risorgimento, a cordial relationship developed between the United States and Italy. Americans supported Italy in its struggle for freedom and independence and admired it for its magnificent past, natural beauties, and cultural and intellectual heritage.

The influx of Italian immigrants, especially to big cities in the United States, however, fostered anti-Italian feelings. Between 1821 and 1904, around 1.8 million Italians arrived in the United States. From 1904 to 1920 alone, over two million more came. ${ }^{2}$ The Italian gained a stereotype as an

${ }^{1}$ Giulio Andreotti, "Foreign Policy in the Italian Democracy," Political Science Quarterly 109 (Summer 1994): 531.

${ }^{2}$ G. E. Di Palma Castiglione, "Italian Immigration into the United States, 1901-4," American Journal of Sociology 11 (Sept. 1905): 183; Rudolph J. Vecoli, "The Significance of 
illiterate, uncivilized, and deprived offender who could not adapt to American life and institutions. To many Americans, Italian immigrants came to seem an undesirable element in the society with uncertain prospects for assimilation.

Nevertheless, naturalization was open to Italians, just as it was to other Europeans. By offering immigrants citizenship through naturalization, the United States, in principle, aimed to create new Americans. U.S. citizenship implied not only an attachment to the new community, but abandonment of former citizenship and responsibilities. During the period between the mass immigration to America in the late nineteenth century and the end of World War I, however, Italy considered emigration as a "safety-valve" for its deprived economy. In the eyes of Italian politicians, emigration would bring financial benefits to Italy along with the intensification of italianitá (Italian character) of the Italians abroad. Italian officials also anticipated that most emigrants would be "birds of passage" and would return to their home country eventually as economically and socially advanced Italian subjects, thus helping overcome the domestic problems of poverty and ignorance. Italian authorities succeeded in encouraging returnees and remittances; the rate of Italian return migration between 1905 and 1915 is striking. During this period, nearly two-million Italian immigrants returned to their country. Two-thirds of the returnees came from the United States, though many of them, feeling neither wholly Italian nor wholly American, went back to the United States. ${ }^{3}$

Italian and American conceptions of and laws on citizenship clashedparticularly in the first two decades of the twentieth century. An exploration of that conflict, especially with regard to Italian Americans' military obligations, shows the overlap of immigration and diplomatic history. The difficulties faced by naturalized Italian Americans when repatriated to Italy forced U.S. policymakers to clarify the meaning of U.S. citizenship and to do so broadly to include the protection of persons who were neither born nor residing in the United States.

\section{American Concepts of Citizenship and Military Service}

United States citizenship is based on three concepts. The first is jus soli, the right of soil, according to which neither the nationality of the parents nor their eligibility for citizenship is decisive for their children's citizenship. Most people in the United States gain citizenship by being born on American soil,

Immigration in the Formation of an American Identity," The History Teacher 30 (Nov. 1996): 11.

${ }^{3}$ See Betty Boyd Caroli, Italian Repatriation from the United States, 1900-1914 (New York, 1973), 54. Dino Cinel, The National Integration of Italian Return Migration, 1870-1929 (Cambridge, 1991), 2. 
and they claim jus soli, the common-law right of the land enshrined in the Fourteenth Amendment of 1868. This principle "is an automatic generator of dual citizenship" for children of immigrants from countries with different principles. ${ }^{4}$ Meanwhile, people born to American parents in foreign countries may claim jus sanguinis, the right of blood. According to this principle, a person need not to be born in a country to be its citizen; citizenship may be obtained through the parents if at least one is a U.S. citizen. In cases where both parents are citizens, the child automatically acquires citizenship if one of the parents resided in the United States for some time prior to the child's birth. But until 1934 the law did not allow U.S. citizenship's transmission by mothers. ${ }^{5}$ The third and the final way of becoming an American citizen is naturalization. Simply put, naturalization means admittance to citizenship, and it is an important type of assimilation-one that is based on the process of changing national allegiance and requires the absolute abandonment of the immigrant's former nationality. ${ }^{6}$

As Rogers Smith asserts, American citizenship has a legally confused, puzzling, politically charged, and contested status. The history of citizenship laws reflects the complicated and conflicted nature of the subject in the United States. Until 1868, the Constitution did not even offer a clear definition of U.S. citizenship or define the relationship between state and national citizenship; states had much power to make decisions about individuals' citizenship. ${ }^{7}$

Dual citizenship emerged as a problem in the United States as early as the second half of the nineteenth century as a consequence of the increase in immigration. The combination of the United States' jus soli rule with other countries' jus sanguinis laws created plural citizenship. This created a major difficulty in assimilating the new immigrants since dual citizenship meant dual allegiance. The Expatriation Act of March 2, 1907, was "the first general statute providing for loss of U.S. nationality." 8 The law stated that "an American expatriate[d] himself by obtaining naturalization in a foreign

4William Rogers Brubaker, "Citizenship and Naturalization: Policies and Politics" in Immigration and the Politics of Citizenship in Europe and North America, ed. William Rogers Brubaker (Lanham, MD, 1989), 115.

${ }^{5}$ Linda K. Kerber, "The Meanings of Citizenship," Journal of American History 84 (Dec. 1997): 834. For more on jus sanguinis, see Thomas Alexander Aleinikoff, David E. Martin, and Hiroshi Motomura, Immigration and Citizenship: Process and Policy, 4th ed. (St. Paul, 1998), 25-43; an act of May 24,1934, stated that a child born abroad to one American parent rather than only the father had the right to U.S. citizenship.

${ }^{6}$ Avery M. Guest, “The Old-New Distinction and Naturalization: 1900," International Migration Review 14 (Winter 1980): 494.

${ }^{7}$ Rogers M. Smith, Civic Ideals: Conflicting Visions in U.S. History (New Haven, 1997), 14, $115,119$.

${ }^{8}$ Aleinikoff et al., Immigration and Citizenship, 120; Peter H. Schuck, Citizens, Strangers, and InBetweens: Essays on Immigration and Citizenship (Boulder, CO, 1998), 185. 
country or taking an oath of allegiance thereto." The passage of this act was a legal consequence of the influx of non-Northern European immigrants to the United States. ${ }^{9}$

The 1907 act was first tested in 1915 by the Supreme Court's MacKenzie v. Hare decision, which upheld the law authorizing the expatriation of an American woman married a foreigner. The decision was based in part on an old American jurisprudence principle that regarded a husband as dominant over his wife. ${ }^{10}$ Mrs. MacKenzie had the right to refurbish her U.S. citizenship when she decided to dissolve marital ties with her foreign husband. Apart from generating multiple citizenship prerequisites based on gender, the significant point in the MacKenzie v. Hare decision is that "voluntary renunciation of citizenship proclaimed in the 1868 Expatriation Act was interpreted...to include voluntary performance of an expatriating act without regard to whether the citizen actually intended or desired to lose his U.S. nationality." 11 The 1922 Cable Act terminated this practice, but MacKenzie v. Hare is worth mentioning, since the case illustrates the conflicted nature of American citizenship.

The National Defense Act of June 1916 defined "every able-bodied male citizen of the United States and all other able bodied males who ha[d] declared their intention to become a citizen of the United States, who [were] between the ages of eighteen and forty-five, [as] members of the unorganized militia, [and] required to bear arms when necessary." 12 Thus the allegiance of certain U.S. citizens or would-be citizens required possible military service. The Selective Service Act of May 1917 made declarant immigrants from friendly countries eligible for the military draft "since it was felt that they received the benefits of their adopted country and should, therefore, share the nation's burden." Additionally, on May 9, 1918, Congress allowed foreigners in the U.S. military to become naturalized without signing a declaration of intention, without paying the naturalization fee, and without passing an English examination. Between 1911 and 1920, 244,300 soldiers became American citizens through military naturalization. ${ }^{13}$

${ }^{9}$ Quote from Richard W. Flournoy, Jr., "Observations on the New German Law of Nationality," American Journal of International Law 8 July 1914): 481; Candice Lewis Bredbenner, A Nationality of Her Own: Women, Marriage, and the Law of Citizenship (Berkeley, 1998), 9.

${ }^{10}$ Henry S. Matteo, Denationalization vs. "The Right to Have Rights": The Standard of Intent in Citizenship Loss (Lanham, MD, 1997), 35.

${ }^{11}$ Aleinikoff et al., Immigration and Citizenship, 121.

${ }^{12}$ Henry B. Hazard, “'Attachment to the Principles of the Constitution' as Judicially Construed in Certain Naturalization Cases in the United States," American Journal of International Law 23 (Oct. 1929): 788.

${ }^{13}$ Quote from Nancy Gentile Ford, Americans All! Foreign-born Soldiers in World War I (College Station, TX, 2001), 52; "Naturalizations since 1907," INS Reporter 26 (Winter 1977-78): 41-46. 


\section{Italian Concepts of Citizenship and Military Service}

According to the Italian Citizenship Act of February 5, 1992, citizenship may be automatically conferred on children born to Italian parents (jus sanguinis), regardless of the place of birth. ${ }^{14}$ Italian citizenship may also be acquired on the basis of specific applications. If an applicant is descended from an Italian citizen by birth, he or she may acquire citizenship by performing military service or civil service and by residing in Italy for two years before the legal age. Applicants born on Italian territory may become Italian citizens by residing in Italy from birth to adulthood. Marrying an Italian citizen is another way to obtain citizenship: Spouses who are married to Italians may apply for citizenship six months after marrying if they are residing in Italy or three years after if they live in a foreign country. Lastly, Italian citizenship may be acquired through naturalization after ten years of residence with proof of sufficient financial resources, an absence of criminal records, and renunciation of the former citizenship if necessary. The period of residence decreases to four years for citizens of European Union countries, five years for stateless people and refugees, and seven years for persons affiliated with Italian citizens.

Narrating the history of Italian citizenship is not easy because sources and research about the evolution of Italian citizenship are limited and insufficient. Eighty years passed between the previous and current Italian Nationality Law. The 1912 statute was revised in order to maintain or to restore "bonds with old nationals and their descendants," because this was considered "more important than creating new nationals." One of the main reasons for this approach to the issue of citizenship was that emigration, rather than immigration, was so prevalent at the time. Italy's aim until the late twentieth century was not to integrate foreigners in the state, but to have good and loyal Italian citizens wherever they resided. In some respects, the 1992 law was a continuation of this attitude: The principle of jus sanguinis was in the main preserved, and Italian nationals who had lost their formal nationality under the previous law were allowed to regain this status. Finally, naturalization of foreign nationals became stricter. In brief, the 1992 law reinforced the 1912 law's objective of having strong bonds with Italian nationals all around the world. ${ }^{15}$

In the late nineteenth and the early twentieth centuries, when Italy's population was the lowest among major European countries as an outcome of emigration (or in some patriots' words, wastage or "hemorrhage"), ${ }^{16}$ Italian

${ }^{14}$ Italian female citizens gained the right of transferring citizenship to their children after January 1, 1948.

${ }^{15}$ Mathias Koenig-Archibugi, "National and European Citizenship: The Italian Case in Historical Perspective," Citizenship Studies 7 (Mar. 2003): 104.

16Richard Bosworth, Italy and the Approach of the First World War (London, 1983), 8. 
citizenship was based strictly on jus sanguinis. Thus the children of Italian immigrants born in the United States automatically became Italian subjects. The jus sanguinis principle of Italian citizenship was defined in the Italian Civil Code. The Kingdom of Italy legally recognized the naturalization of its subjects in foreign countries and the renunciation of Italian citizenship, but with a qualification. While Article 11 of the Italian Civil Code provided for an Italian subject to expatriate himself if he had acquired citizenship in a foreign country, Article 12 stipulated that the loss of Italian citizenship did not imply an exemption from past obligations, especially military service, "nor from the penalties imposed on those who bear arms against their country." 17 The new nationality of a former Italian male subject did not liberate him from his military duties in the Italian armed forces since he was born an Italian. Italy recognized a father's naturalization as an exemption from the military for his sons who were born on foreign soil--but only if the father had naturalized before their birth. Those children born to Italian immigrants who had yet to naturalize were seen as Italian subjects since citizenship was based on the idea of inheritance rather than place of birth.

According to U.S. laws of citizenship, birth on American soil was sufficient for a person to be American. Moreover, an American-born child whose parents were not U.S. citizens had the right to choose a citizenship after the age of eighteen. But Italy held that the children of any subject, no matter where these children were born, took the status of the parent. ${ }^{18}$ That situation provoked the controversy between Italy and the United States over naturalization and the definition of citizenship. In the Italian Parliament on December 18, 1899, Minister of Foreign Affairs Emilio Visconti-Venosta described the problem between Italy and the United States with these words:

Practically, from the Italian point of view, the question presents itself as follows: our Civil Code establishes at Article 4 that the son of a father who is an Italian citizen is himself an Italian citizen, and at Article 11 it declares that, whoever has obtained naturalization in a foreign country loses his Italian citizenship. Therefore, the Italian subject who has fixed his residence in the United States finds himself confronted by this alternative: either to remain faithful to his nationality of origin and renounce those political

${ }^{17}$ Secretary of State ad interim to Senator Henry Cabot Lodge, June 9, 1915, U.S. Department of State, Foreign Relations of the United States: Diplomatic Papers, 1915 (Washington, 1924), 560 [Hereafter FRUS, year of documents].

18John Horace Mariano, The Italian Contribution to American Democracy (Boston, 1921), 68-69. 
and administrative rights which, in the great centres of emigration, would be the most efficient means of influence and protection of his interests; or else to accept the nationality of the country he resides in, losing de jure and de facto his Italian citizenship. ${ }^{19}$

And the Italian government continued to consider its emigrants, many of whom were naturalized Americans, liable for military service in Italy. The Italian Citizenship Law of June 13, 1912, did not provide any essential change in approach. It repealed all the previous laws, but like them it still contained the condition that loss of nationality did not mean exemption from military service. As Ambassador Thomas Nelson Page indicated, that situation instigated "much dissatisfaction among [America's] naturalized citizens of Italian birth who return[ed] to Italy on visits or for business purposes, and [was] liable to cause friction." 20 In addition, with the 1912 law, as historian Betty Boyd Caroli writes, "renewing Italian citizenship cost nothing, and it could be accomplished by returning to reside in Italy for two years." 21 Donna Gabaccia argues that "the main tie between Italy's government and Italy's citizens was through universal male military service"-but making Italian males perform their military service was not easy. ${ }^{22}$ Neither Italian culture nor the structure of Italy's military encouraged popular devotion to military service. These problems multiplied when young men lived outside Italian jurisdiction.

After unification in 1866, the Italian army had four responsibilities: oversee external defense, fight overseas wars, foster italianità, and support the civil power. It performed none of these duties effectively. In terms of technology and organization, the Italian armed forces lagged behind other European powers. The army-in which officers and men occasionally did not speak the same language because of regional differences-was isolated from foreign policy, politics, and national life under a rigid caste system and bureaucracy. Its use in domestic conflicts encouraged popular resentment. ${ }^{23}$ Government officials, premiers, and ministers of foreign affairs held the

${ }^{19}$ Visconti-Venosta quoted by Minister of Foreign Affairs Tommaso Tittoni, Mar. 3, 1905, in Italy's Foreign and Colonial Policy: A Selection from the Speeches Delivered in the Italian Parliament by the Italian Foreign Affairs Minister Senator Tommaso Tittoni (1903-1909), trans. Bernardo Quaranta di San Severino (London, 1914), 168. When citing his predecessor in the Italian Parliament, Tittoni stated that he could not better explain the difficulties of the question.

${ }^{20}$ Ambassador Thomas Nelson Page to the Secretary of State, Sept., 9, 1914, FRUS, $1914,406$.

${ }^{21}$ Caroli, Italian Repatriation, 86.

22Donna R. Gabaccia, Italy's Many Diasporas (London, 2000), 36.

23John Gooch, Army, State and Society in Italy, 1870-1915 (London, 1989), 171. R. J. B. Bosworth, Italy, the Least of the Great Powers: Italian Foreign Policy Before the First World War (Cambridge, 1979), 21. 
armed forces in low regard. Five-time prime minister Giovanni Giolitti, whose governments set in motion large increases in the military budget, nonetheless once remarked, "Italian families had pushed into the Officer Corps those "boys whom they did not know what to do with, the idle and the mentally deficient."'24 Italy's many military disappointments contributed to the military's poor reputation. The war with Turkey over Libya in 1911 could have been an important step toward making Italy a significant colonial power and a demonstration of the Italian army's reform and modernization; instead, by 1912 the Italian military was completely bogged down in North Africa. In short, in the period before the First Word War, the Italian Army continued to be distanced from both the society and the state. ${ }^{25}$

\section{Sources of Controversy}

Of course, the United States had periodically clashed with other countries about the military service of the naturalized Americans. Great Britain's impressments of naturalized (or allegedly naturalized) American seamen contributed to the outbreak of the War of $1812 .{ }^{26}$ In the late nineteenth century, immigrants from Russia and Austria-Hungary were regarded as draft evaders in their home countries. Although the issue of military service sparked the sharpest disagreement between the United States and Italy during World War I, the U.S. State Department noted the issue even earlier, in 1901:

Italian subjects between the ages of 20 and 39 years are liable for the performance of military duty under Italian law, except in the case of an only son, or where two brothers are so nearly of the same age that both would be serving at the same time, in which event only one is drafted, or when there are two sons of a widow, when only one is taken.

Naturalization of an Italian subject in a foreign country without consent of the Italian government is no bar to liability to military service....

There is no treaty between the United States and Italy defining the status of former Italian subjects who have become American citizens. ${ }^{27}$ 
This notice indicates the essential points of discord between the United States and Italy. Former Italian subjects in theory still had to perform service in the Italian military. Consequently, the U.S. government warned naturalized males of Italian origin about journeys to Italy, since there would be no grounds on which to protect them from compulsory military service. Italian men between the ages of twenty and twenty-eight were liable to serve in the active army; those between twenty-nine and thirty-one were liable to serve in the reserve army; and those between thirty-two and thirty-nine were liable to serve in the territorial reserve army. Though no longer subject to the draft, men older than thirty-nine still risked imprisonment if they had not obtained a pardon. ${ }^{28}$

Italy passed a new Emigration Act on January 30, 1901. Its enactment "signified cognizance on the part of the Italian government of the need to regulate and report on migration from its borders." 29 In order to have a more organized migration policy, a Commissariato dell'Emigrazione [Emigration Commissariat] was established within the Ministry of Foreign Affairs. One of its main tasks was to improve the situation of Italian immigrants abroad. The Commissariat also published bulletins (Bollettini dell'Emigrazione) about the nature, characteristics, and future of Italian emigration and the emigrants' problems. With an amendment in February of the same year, the new emigration act "assigned to the Banco di Napoli (Bank of Naples) the responsibility of forwarding remittances from Italians living in other countries."30 More important, between 1902 and 1914, Italians abroad were welcomed back to Italy. Tittoni stated in 1904 that "if they return[ed], the mother country [would] never refuse to recognize them as her sons."'31

When Italian Americans went to Italy, they were officially received as real Italians, although many felt culturally removed from their homeland. Nevertheless, the visiting Italian Americans were obliged to perform their military service once they entered the kingdom. With that, the conflict became clear. The American government could not prevent its naturalized citizens' military service in the Italian army, and Italian officials upheld the articles of their Civil Code. American concern about the Italian immigrants and their status in the United States became clear in the diplomatic correspondence by 1907 : 398.

${ }^{28}$ Ambassador Thomas J. O'Brien to the Secretary of State, June 11, 1913, FRUS, 1914,

${ }^{29}$ Caroli, Italian Repatriation, 53.

${ }^{30}$ Ibid., 57.

${ }^{31}$ Ibid., 72. 
The volume of immigration from Italy to the United States has in recent years become so large that it forces itself upon the consideration of this Government. Many of the Italians who thus come to this country intend to remain and establish their homes in the United States....[But] some of these naturalized citizens, drawn by a natural affection for their parent country, desire to revisit it and do revisit it, and their status is at present ill-defined and the cause of misunderstandings which, as this Government believes, could be removed and rendered improbable of recurrence by a conventional agreement defining their status and their rights. ${ }^{32}$

In 1894, Italy had refused to sign a naturalization treaty, but in 1907, the American ambassador, Lloyd C. Griscom, perceived a new willingness on the part of Italian foreign affairs minister Tommaso Tittoni to change the Civil Code:

Mr. Tittoni received the suggestion [about a naturalization convention] most favorably and said that that hitherto the Government of Italy had been disposed to regard the Civil Code [requiring military service] as almost unalterable. $\mathrm{He}$, on the contrary, believed that the national code of laws should be altered to meet changed conditions. He thought that an agreement between the United States and Italy would be a useful and necessary measure, and therefore he was entirely willing to begin negotiations, and would at once appoint a commission to study the matter and report to him. ${ }^{33}$

Tittoni appointed a committee that later reported to him and to Parliament about negotiations. But, in the end, the foreign minister expressed "the Italian Government's regret at being compelled to decline [the United States'] offer to open negotiations for the conclusion of a naturalization treaty." 34 Rather than opening international negotiations about naturalization, Italians preferred to make alterations in their domestic laws. 390.

${ }^{32}$ Secretary of State Elihu Root to Ambassador Henry White, Feb. 11, 1907, FRUS, 1914,

${ }^{33}$ Ambassador Lloyd C. Griscom to the Secretary of State, June 5, 1907, FRUS, 1914, 393.

${ }^{34}$ Griscom to the Secretary of State, June 19, 1908, FRUS, 1914, 395. 
The only new development was the law of March 20,1907, which amended Article 12 of the Civil Code concerning the military service requirement of Italians abroad. According to the new regulation, a former Italian subject who returned to Italy after reaching thirty-two years of age was considered liable for the territorial reserve army like Italian residents but would not be subject to punishment for previous absence as long as he had gone to the United States before the age of sixteen. Italian subjects qualifying for exemption from military service could do so as long as they resided in a foreign country, although they still had to enlist in the territorial reserve army in the presence of Italian diplomatic or consular authorities. ${ }^{35}$

The emigration law of July 17, 1910, deleted Article 12 from the Italian Civil Code but introduced new regulations concerning emigrants' obligations for military service. The law exempted Italian males born and residing abroad or who had emigrated to a foreign country before their seventeenth birthday, regardless of their father's citizenship, from serving in the Italian armed forces until the time of their return to the Italy. That exemption was not valid at times of "general mobilization." Italian subjects born or residing abroad who reentered Italy before their thirty-third birthday were required to present themselves immediately to the military districts for service. Individuals could enter Italy in "exceptional cases" for a period no longer than two months after obtaining permission from diplomatic and consular authorities, although if they could prove that they were continuing "regular course of studies," the period of exemption from military service could be extended. ${ }^{36}$ In brief, the Italian government's control over its emigrants remained in place with the ongoing and new laws and regulations.

\section{American Duty to American Citizens}

As a consequence of military preparedness, universal military training, Americanization programs, and the like, the U.S. Army in World War I consisted of a multiethnic combination of soldiers. Nearly half-a-million immigrants from forty-six different nationalities were drafted into the U.S. armed forces, and more than 18 percent of U.S. soldiers were foreign-born. Many immigrants from Southern and Eastern Europe believed that the war would be an opportunity both to make their homelands independent of the

\footnotetext{
${ }^{35}$ Ambassador Thomas Nelson Page to the Secretary of State, Nov. 4, 1913, FRUS, 1914, 400, Inclosure 1. The law of Dec. 24, 1911, Article 91, stated that members of the territorial army could be called on to receive military instruction when it was deemed necessary; see Ambassador Thomas J. O'Brien to the Secretary of State, June 11, 1913, FRUS, 1914, 398-99.

${ }^{36}$ Ministero degli Affari Esteri, Commissariato dell'Emigrazione [Ministry of Foreign Affairs, Emigration Commissariat], Leggi, Regolamenti e Norme Complementari della Legge sull'Emigrazione [Complementary laws, regulations and norms of the Emigration Law] (Rome, 1910), 11-12, 105.
} 
German, Austrian, and Ottoman empires and to prove their loyalty to the United States and make their ethnicity acceptable there. When the United States became an ally of Italy in 1917, Italian immigrants were among the ethnic groups in the U.S. Army who felt patriotism and ethnic pride simultaneously. The war did in fact reverse some of the negative stereotypes of Italians accumulated from the late nineteenth century.

Similarly, a recent study on Italian Americans in New Haven, Connecticut, found that members of the New Haven colonia developed ways to show loyalty to both their adoptive and native countries. For the Italians in New Haven, serving in the American army meant not only supporting Italian troops, but it also allowed New Haven's Italian Machine Gun Company to "follow a cherished volunteer militia tradition in New Haven." 37 The Italian immigrants of New Haven saw themselves as good new Americans who did not forget their past. They supported their mother country first by offering financial assistance to Italy through aid organizations-especially the Italian Red Cross-and later by serving in the U.S. Army. Thus Italians in the United States, naturalized or not, perceived the war both as an opportunity for their homeland and a chance to prove their loyalty to their adoptive country.

In Italy, meanwhile, the armed forces underwent extensive changes, especially after Antonio Salandra replaced Giolitti as prime minister in 1914. Salandra cooperated with the nationalists in preparing to bring Italy into World War I. The Italian Army-lacking in clothing, equipment, and munitions-was in poor condition and had been Italy's greatest obstacle to entering the war. Furthermore, Italy's army was out of touch. As late as 1912, Minister of War Paolo Spingardi claimed not to know the details of the country's Triple Alliance with Germany and Austria and that he had been told by Foreign Minister Antonino di San Giuliano that there were "no military provisions contained in the agreement." 38 As the Salandra cabinet moved Italy diplomatically away from the Central Powers and toward the Allies, it also engaged in a rushed overhaul of the armed forces. Italy's neutrality ended on April 26, 1915, with the Treaty of London. The agreement granted Italy vast territories, including South Tyrol, Trentino, the Istrian Peninsula, and a section of Dalmatia in return for Italy's joining the Allies. On October 19, Salandra declared that the war would elevate Italy to the status of a great power, "one of the prime movers of world politics." 39 The war was a golden opportunity for Italy to gain prestige and power, but it

${ }^{37}$ Christopher M. Sterba, Good Americans: Italian and Jewish Immigrants during the First World War (New York, 2003), 35.

${ }^{38}$ Quote from Bosworth, Italy and the Approach, 44.

${ }^{39}$ Ronald S. Cunsolo, Italian Nationalism: From Its Origins to World War II (Malabar, FL, 1990), 225-26. 
needed a strong army composed of loyal and patriotic Italian subjects in order to succeed.

Salandra's vision did not easily become reality. During the First World War, 5.7 million men were enlisted-more than the number of men with the right to vote in the 1913 elections. Nearly 600,000 Italian soldiers died and 500,000 were wounded, and the Italian government's wartime spending between 1915 and 1918 exceeded its entire outlay from 1861 to 1913. Like the United States, Italy entered a period of full mobilization, preparedness, and Italianization, but that was no easy task for a country that had called up only about 24 percent of its available conscripts in 1913. Without a doubt, Italy was in the need of its nationals abroad.

During World War I, most Italian immigrants preferred to stay in the United States, though the Italian government began urging its emigrants to return home for active duty in May 1915. The Italian government also sought to attract back nationals who had dodged the draft by emigrating. ${ }^{40}$ The cases of five men caught between Italian and American concepts and policies of citizenship show how, perhaps especially in wartime, the United States broadened its definition of U.S. citizenship to protect persons outside the United States. Three of them were clergy: Reverend Raymond Carrá, Catholic pastor of St. Patrick's Church in New Orleans, Reverend Dominic A. Cassetta, an Episcopal priest from Long Island and curate of St. Augustin's Chapel, Trinity Parish, in New York City, and Reverend Gustave G. Danchise, a Presbyterian clergyman in New York. ${ }^{41}$

Reverend Carrá, born in Vicari, arrived in the United States when he was ten years old in 1890. He resided in Louisiana continuously for twenty-four years and became a naturalized American citizen, and then returned to Italy at the age of thirty-four in 1914. But when he arrived to visit his relatives for three months, he was detained for military service in the Italian territorial army. ${ }^{42}$ Reverend Cassetta, born on May 30, 1878, at Auleta in the province of Salerno, went to the United States when he was five years old. His father, Aniello Cassetta, became naturalized when his son was thirteen. The reverend returned to Italy for academic purposes in 1916 and was

${ }^{40}$ For details about Italy's migration and nationality policy in relation to military service, see David A. Cook-Martín, "Making and Unmaking Nationals: 150 Years of Migration between Argentina, Italy, and Spain" (PhD diss., University of California, Los Angeles, 2005), ch. 5.

${ }^{41}$ Ambassador Thomas Nelson Page to the Secretary of State, Sept. 15, 1914, FRUS, 1914, 406. That two of these clergymen were Protestant was, of course, an unusual coincidence. The author has no evidence as to whether Cassetta and Danchise's Protestantism resulted from modern circumstances or whether they descended from older Italian Protestant communities such as those described in Salvatore Capponetto, The Protestant Reformation in Sixteenth-Century Italy, trans. Anne C. Tedeschi and John Tedeschi (Kirskville, MO, 1998).

42Page to the Italian Minister for Foreign Affairs, Nov. 20, 1914, FRUS, 1914, 414, Inclosure 3. 
apprehended in Naples with his wife and child, though he possessed an American passport. Reverend Danchise was a naturalized American citizen of Italian birth. When he returned to Italy due to ill health, he was held for military service under notice by the mayor of Sarzana in the province of Genoa. ${ }^{43}$

Ambassador Page requested that Italian officials return these American citizens to the United States as soon as possible. Page believed that the detention "especially of the class represented by the priests and clergymen and married men, because of Italy's military regulations, ha[d] done more to arouse an uncertainty of feeling in the minds of [American] people."44 Italy's response to U.S. requests for the release of the three clergymen illustrates the Italian approach to the problem of naturalization and military service. According to the conscription lists for 1880, the year of Carrás birth, Reverend Carrá was a renitente, a person who had refused to perform his military duties. Since he had left Italy at the age of ten and returned at the age of thirty-four, however, he could gain relief from military service by presenting himself to the Consiglio di Leva (Council of Recruitment). He was allowed to go back to the United States following the legalization of "his status before the military authorities of the Kingdom." 45

Since Cassetta (or Cascetta, as stated in later accounts), like Carrá, had passed the age of thirty-two, he was released by the Italian authorities in a similar manner. He was enrolled the territorial army of Italy but had the right to return to his adoptive country. Nevertheless, the official at the foreign office, Marquis Luigi Borsarelli di Rifreddo, reminded Ambassador Page that Article 12 of the Italian Civil Code was in force when Cassetta acquired American citizenship and "when he should ha[ve] been in Italy performing his duties as a soldier." 46

Reverend Danchise apparently was less fortunate. According to official records of the Italian Ministry of War, he had not responded to the call of enlistment in Sarzana for the years 1892, 1893, or 1894. At the time of the U.S. government's request for his return to America, his status under Italian conscription laws was unclear, and thus he could not be allowed to return to the United States. ${ }^{47}$ In sum, the Italian government maintained its right to the military service of these Italian-born Americans, though ultimately two of the three individuals were released. This policy was enforced despite the

\footnotetext{
${ }^{43}$ Secretary of State William Jennings Bryan to Page, Sept. 23, 1914, FRUS, 1914, 408; and Page to the Secretary of State, Dec. 14, 1914, FRUS, 1914, 414, Inclosure 4.

${ }^{44}$ Page to the Secretary of State, Nov. 3, 1914, FRUS, 1914, 411.

45 Page to the Secretary of State, Dec. 14, 1914, FRUS, 1914, 418, Inclosure 15Translation.

46Page to the Secretary of State, Jan. 11, 1915, FRUS, 1915, 555, Inclosure-Translation.

${ }^{47}$ Page to the Secretary of State, Dec. 14, 1914, FRUS, 1914, 418-19, Inclosure 16-
} 
naturalization of all three individuals as U.S. citizens. American rights of citizenship carried little weight with Italian officials.

The combination of Italian immigrants' readiness and capacity to serve in the U.S. armed forces and pressure by the Italian government to compel returnees to serve in its military prompted U.S. policymakers more vigorously to enforce an expansive concept of U.S. citizenship. Frank (Francesco) Ghiloni's military-service case reveals the details of the critical divergence between U.S. and Italian policies on citizenship and naturalization. Ghiloni was born in Marlborough, Massachusetts, on August 4, 1885, and his father was naturalized on February 12, 1886. Thus Ghiloni was born an Italian subject according to Article 12 of the Italian Civil Code. He went to Italy when he was two years old and returned to the United States after ten years, in May 1897. In June 1914, he again went to Italy temporarily for health reasons and was impressed in the Italian Army. ${ }^{48}$ As in the case of the three clergymen, U.S. ambassador Thomas Nelson Page asked for the return of Ghiloni to the United States, but the Italian Ministry of War decided that it was impossible to exempt Ghiloni from liability to military service since his father was naturalized as an American citizen after his son's birth. ${ }^{49}$ The State Department insisted on Ghiloni's release by the Italian authorities since he "was born a citizen under the law of [the United States]...and ha[d] evidently made a practical election of American nationality." 50 Italian authorities repeated their decision, insisting that Ghiloni could not be exempted from military service in Italy under Article 12 of the Civil Code, which was still in force when he was first called to military service. ${ }^{51}$

In the end, a third country solved the problem of Frank Ghiloni. In September 1914, the American Embassy in Rome received a letter from Ghiloni's brother, Alfred R. Ghiloni, stating that Frank was "in poor health and believing to be suffering from gall stone." 52 Normally, that kind of an illness would be grounds for exemption from service, but Italian authorities still refused to release him. Italian officials informed the United States that Ghiloni would receive the necessary medical treatment from army surgeons. But another letter from Alfred Ghiloni, dated December 25, 1915, indicated that the Austrian army had taken Frank Ghiloni prisoner on October 21. According to the Central Information Bureau of the Red Cross, Ghiloni had

\section{Translation.}

${ }^{48}$ Ambassador Frederick Penfield to the Secretary of State, U.S. Embassy, Vienna, Mar. 16, 1916, FRUS, 1916, 405, Inclosure 2; "Dual Nationality-Military Service Case of Frank Ghiloni," The American Journal of International Law 10 (Oct. 1916): 474.

${ }^{49}$ Page to the Secretary of State, May 18, 1915, in "Dual Nationality-Military Service Case of Frank Ghiloni," 462.

${ }^{50}$ Secretary of State Robert Lansing to Ambassador Page, July 20, 1915, in ibid., 463.

${ }^{51}$ Page to the Secretary of State, Aug., 27, 1915, in ibid., 465.

52Page to the Secretary of State, Sept. 4, 1915, in ibid., 467. 
indeed been wounded and taken prisoner in October 1915 and then transferred to Mauthausen, Austria, in November. The United States requested the release of Ghiloni by Austro-Hungarian officials since he had been impressed in the Italian Army involuntarily and was a U.S. citizen by birth. The Austro-Hungarian Ministry of Foreign Affairs decided to release Ghiloni on the condition that he make a sworn affidavit that he would not bear arms against the Central Powers, would not leave American territory until the war was over, and would not be compelled to do military service by the Entente powers. Frank Ghiloni was released on June 19, 1916, and returned to the United States via Scandinavia. Italy, meanwhile, had made no attempt to secure his release from Austro-Hungarian custody. ${ }^{53}$ In terms of his repatriation to the United States, Frank Ghiloni benefited more from being a war prisoner of the Central Powers than from being an American citizen.

The Ugo da Prato case is another significant indication of the citizenship and naturalization problems between Italy and the United States in the $1910 \mathrm{~s} .{ }^{54}$ With the da Prato case, the U.S. government adopted a more forceful tone in light of Italy's refusal both to alter its citizenship laws and to attend an international meeting about naturalization. The case is also noteworthy since it attracted the attention of Senator Henry Cabot Lodge of Massachusetts, a forceful champion of American national rights as well as a notorious critic of Italian immigration, at least as far as peasant and working-class southern Italians were concerned. Additionally, it revealed the growing problem of naturalization and expatriation between the United States and Germany after 1914, in spite of the Bancroft Treaty signed in 1868.

Mario Ugo da Prato was born in Boston on August 25, 1895. His father, Antonio da Prato, was born in Barga in the Italian province of Lucca in 1859, migrated to America, and was naturalized in Boston on March 19, 1892, three years before the birth of his son. Thus Ugo da Prato was born an American citizen according to the principles of jus soli and jus sanguinis in tandem, and, according to Ambassador Page, "even under the Royal Italian Government's interpretation of the law of dual nationality, [was] clearly exempt from military service as a native-born American citizen." 55 He was nevertheless called up for military duty in 1914 while he was residing in Italy, studying architecture at the art school in Lucca.

53Ibid., 467-76.

${ }^{54}$ For the da Prato case, see FRUS, 1914, 422-23; FRUS, 1915, 557-79; "Dual Nationality," in "Supplement: Diplomatic Correspondence Between the United States and Belligerent Governments Relating to Neutral Rights and Commerce," American Journal of International Law 9 (June, 1915): 369-75.

${ }^{55}$ Ambassador Page to the Minister of Foreign Affairs, Nov. 27, 1914, FRUS, 1914, 422-23. 
Italian authorities accepted that Ugo da Prato would not be obliged to perform military duty in the active Italian army if his father was naturalized before his birth. But there was a sticking point: Ugo da Prato had gone to Italy in 1911 with his father and had remained ever since. Antonio da Prato went to Italy three years earlier on business related to the Panama-Pacific Exposition planned for San Francisco in 1915 and took his son with him. ${ }^{56}$ The da Pratos' continuous residence in Italy from that year reconstructed their Italian citizenship because, according to the law of June 13, 1912, they repatriated themselves after two years of residence. The Italian minister of foreign affairs, Sidney Sonnino, explained to American authorities:

The Ministry of War has been obliged to find that Mr. Antonio da Prato, in accordance with the provisions of Article 9, Number 3 of the law of June 13, 1912, numbered 555, has reacquired Italian citizenship, because of his having returned to the land of his nativity and resided therein for more than two years....For these reasons, young Mario Ugo da Prato is found to be an Italian citizen, amenable to military service; that his name cannot be removed from the recruiting lists of the Kingdom; and that he must soon respond to the call of the colors and serve as a soldier in the Italian army. ${ }^{57}$

American officials responded by referring to their own laws and regulations about expatriation. In a dispatch to Ambassador Page, Robert Lansing, then interim secretary of state, brought up Section 2 of the American Expatriation Act of March 2, 1907, which, while admitting that a residence of two years of a naturalized American in his native country would imply the loss of his citizenship, asserted, "Such presumption [could be] overcome on the presentation of satisfactory evidence to a diplomatic or consular officer of the United States under such rules and regulations as the Department of State may prescribe." Specifically, if a naturalized American could present evidence to demonstrate that he had gone to his homeland for commercial reasons and intended to return to his adopted country, by the circular instruction of May 14, 1908, his American citizenship would be retained.58 Thus the restored Italian citizenship of Ugo da Prato clashed with the American laws of expatriation.

${ }^{56}$ Secretary of State ad Interim, Robert Lansing to Page, June 14, 1915, FRUS, 1915, 565.

${ }^{57}$ Page to Lansing, June 17, 1915, FRUS, 1915, 567, Inclosure 1-Translation.

${ }^{58}$ Lansing to Page, Aug. 4, 1915, FRUS, 1915, 572.

${ }^{59}$ Ibid., 571. 
American public opinion, Lansing insisted, was hostile to Italy's detention of da Prato, and the American press called on the Italian government to consent to his return to the United States. ${ }^{59}$ The case became well known when The New York Times published the State Department's extensive correspondence between Lansing and Senator Lodge on the subject of dual nationality. The Times declared that the da Prato case was unquestionably very important for the United States since "it outline[d] a policy of [the U.S.] Government toward many foreigners claiming American citizenship."60 Public and diplomatic pressure had an effect. Ugo da Prato was released by the Italian authorities on August 24, 1915, on the condition that he would leave Italy within two months, since "da Prato intend[ed] to reestablish his residence abroad." 61

There are several notable aspects to the process that resulted in da Prato's release. The first is Henry Cabot Lodge's involvement, which on the surface contradicts his anti-Italian and nativist reputation. Lodge "justified imperialism abroad and immigration restriction at home in terms of Anglo-Saxon superiority," notes one respected historian of Italian immigration. ${ }^{62}$ Lodge "longed for a pure Anglo-Saxon America," remarks another scholar. ${ }^{63}$ After the New Orleans lynching in 1891, Lodge referred to Italians as criminals and paupers who infected the United States with diseases such as cholera and argued that the quality of American citizenship had to be protected by "an intelligent restriction" that comprised "consular inspection in the country of departure" and "some such fair and restrictive test as that of ability to read and write." 64 As a young politician, Lodge had worked with likeminded, upper-class Harvard graduates in the Immigration Restriction League, which was dedicated to hampering the immigration of "inferior" races-Italians, Russians, Hungarians, Greeks, and Asians-by applying the literacy test. 65

Yet in 1915, Lodge adamantly defended the rights of Ugo da Prato. On June 5, Lodge sent Lansing certified copies of the court record of Antonio da Prato's naturalization and the birth certificate of his son. Lodge also pointed out the jus soli principle of American citizenship by referring to the Fourteenth Amendment and advised taking the strongest action against

${ }^{60}$ New York Times, June 22, 1915.

${ }^{61}$ Chargé Peter A. Jay to the Secretary of State, Aug. 24, 1915, FRUS, 1915, 576, Inclosure-Translation.

${ }^{62}$ Vecoli, "The Significance of Immigration," 14; see also Karl Schriftgiesser, The Gentleman from Massacbusetts: Henry Cabot Lodge (Boston, 1944), 110-17.

${ }^{63}$ Gary Gerstle, "Theodore Roosevelt and the Divided Character of American Nationalism," Journal of American History 86 (Dec. 1999): 1296.

${ }^{64}$ Henry Cabot Lodge, "Lynch Law and Unrestricted Immigration," North American Review 152 (May 1891): 604-12.

${ }^{65}$ Smith, Civic Ideals, 364.

${ }^{66}$ Senator Henry Cabot Lodge to the Counselor of the Department of State, June 5, 1915, FRUS, 1915, 558. 
Article 12 of the Italian Civil Code, otherwise U.S. officials would "find [themselves] in a very awkward position with [their] large body of naturalized citizens." 66

Lansing, an experienced international lawyer, replied to Lodge by referring to the details of the Italian Civil Code and the principles of jus soli and jus sanguinis. ${ }^{67}$ Lansing added that the American ambassador in Rome had been directed to press the Italian government for the immediate release of Ugo da Prato. He concluded that "dual nationality [was] not a theory or doctrine promulgated by the department, but [was] the unavoidable result of the conflicting laws of different countries." 68

Lodge responded in an annoyed manner, stating that he was familiar with the doctrines of jus soli and jus sanguinis, but that the essential point for the United States was to abstain from "abat[ing] in any way its duty to those who under its own Constitution and Laws [were] American citizens." 69 Ugo da Prato was an American citizen, and he had to be treated as an American, both in the United States and Italy. While Lodge surely ranked among the most avid of the Boston Brahmin immigration restrictionists, da Prato, an architecture student from Lucca, was the sort of cultivated northern Italian whom educated Americans admired, rather than the impoverished southern Italians whom they often despised. Moreover, Lodge ardently believed that the U.S. government had a duty to protect the citizenship of its naturalized citizens when they were abroad. His intervention on behalf of da Prato showed both his dedication to expanding the international authority of the United States and his responsibility as a Massachusetts senator to pursue the case of a constituent.

\section{Dual Citizenship and a Failed Naturalization Treaty}

Lodge's zeal for protecting the rights of naturalized Americans was also motivated in part by changes to Germany's citizenship law. The United States signed the Bancroft Treaty concerning citizenship and naturalization with the North German Confederation and with the German speakingstates on February 22, 1868. This treaty stated:
Art. 1. Citizens of the North German Confederation, who become naturalized citizens of the United States of America and shall have resided uninterruptedly within the United States five years, shall be held by the North German Confederation to be American citi- zens, and shall be treated as such... 
Art. 2. A naturalized citizen of the one party on return to the territory of the other party remains liable to trial and punishment for an action punishable by the laws of his original country and committed before his emigration; saving, always, the limitations established by the laws of his original country....

Art. 4. If a German naturalized in America renews his residence in North Germany, without the intent to return to America, he shall be held to have renounced his naturalization of the United States. ${ }^{70}$

These conditions were also valid for a naturalized German citizen who was originally American.

The Bancroft Treaty was in effect until Germany enacted an Imperial and State Citizenship Law on July 23, 1913. That law allowed a former German subject to return to his German citizenship without going back to Germany and permitted "a German about to become naturalized in a foreign country to retain, so far as Germany is concerned, his German [citizenship], notwithstanding the acquisition of foreign citizenship." 71 Previously, ten years of residence abroad resulted in the loss of German nationality. But the new citizenship law of Germany invalidated the articles of the Bancroft Treaty by emphasizing the principle of jus sanguinis rather than jus soli, while providing the possibility of repatriation of its former subjects without their residing in Germany.

The new law also legalized the doctrine of dual allegiance by offering German citizenship to its former subjects who had already gained another country's citizenship. In 1913, a German scholar argued that the law "aim[ed] to facilitate as far as possible the reinstatement of lost members of [the German] population as citizens again." The head of the U.S. Bureau of Citizenship noted that "the performance of services to the state rather than domicile within its territory" became the basis for German citizenship. ${ }^{72}$ German subjects abroad lost their citizenship if they entered the service of a foreign country without permission from the German government or if they had actually deserted from the army or failed to obtain a decision as to their military liability at the proper time. The law also provided Germans-

70"The German Imperial and State Citizenship Law," American Journal of International Law 9 (Oct. 1915): 942.

71 Ibid., 939.

72Ibid., 940; Flournoy, “Observations," 479.

${ }^{73}$ Flournoy, "Observations," 481. 
except for men liable for military service-with the right of expatriation. ${ }^{73}$ Finally, Germany's new citizenship law allowed a German subject who was in the process of becoming a naturalized citizen of another country to retain his German citizenship with the written consent of the competent authorities. ${ }^{74}$

Germany's encouragement of dual citizenship disturbed Lodge, since he believed the United States to be "the champion against the doctrine of the abandonment of indefeasible allegiance" and, therefore, against dual citizenship. ${ }^{75}$ His concern was valid. As noted above, beginning in the late nineteenth century, the United States wanted to organize an international naturalization convention in which it could persuade Italy to sign a naturalization treaty. The United States had already signed naturalization treaties with Germany (although that treaty was no longer valid), Austria-Hungary, Belgium, Denmark, Great Britain, Norway, Sweden, and Portugal to resolve conflicting claims upon naturalized citizens. ${ }^{76}$ The United States, however, could not settle the question of citizenship with Russia or the Ottoman Empire, both of which abided by the principle of jus sanguinis.

The U.S. government, which opposed dual allegiance, aspired to sign a naturalization treaty with Italy similar to the Bancroft Treaty. If a person wanted to be an American, the proposed treaty demanded, he had to renounce his former nationality and had to reside in the United States permanently. According to U.S. officials, the requirement for adopted citizenship was residence in the adopted country. Therefore, if naturalized citizens returned to their native lands, they would lose their U.S. citizenship. The second point in the proposed agreement was connected to the first: If a naturalized American returned to his original country permanently, he could be punished for his past crimes in that country. These were the conditions that the United States government requested from the Italians. Should former Italian subjects who had become naturalized Americans wish, they would have the opportunity of repatriation in Italy, and they would be responsible for their past crimes if they returned to Italy for good.

U.S. officials also asserted that they did not have "any desire to intervene [on] behalf of any Italian who ha[d] remained in the United States only long enough to secure naturalization and then ha[d] returned to Italy in the hope of there residing as an American citizen, exempt from the operation of Italian military law." 77 In brief, the abandonment of indefeasible allegiance would damage the prestige of the United States in international affairs and 
would bring the American attempt for an international naturalization convention with Italy to an end.

Despite this last provision and several American requests, Italy refused to join a convention. Germany's new citizenship law had attracted the attention of Italian foreign minister Sonnino just as the U.S. government requested that the Italian government sign a naturalization treaty. American officials argued that most European countries, including Germany, had signed similar treaties in the nineteenth century. When Ambassador Page visited Sonnino to discuss the issue and to suggest an international naturalization convention, however, the foreign minister raised the United States' latest experience with Germany. ${ }^{78}$ The Italians also declined to sign a treaty because it would have required significant modifications to their domestic laws. They insisted upon enforcing the Italian law of nationality and military service and considered naturalized Italians abroad to be "liable for the performance of military service in Italy, if such service had not already been performed before emigration." 79 Traditional European concepts of citizenship, combined with the exigencies of war mobilization, prevented the Americans from seeing their concept of citizenship become transatlantic.

Accordingly, complaints from Italian American citizens about being forced into Italian military service persisted throughout World War I. After the American entry into the war, the Italian American soldiers' problems continued. Despite their service in the U.S. Army, they could be listed as deserters in the Italian army. With General Order No. 33 of April 6, 1918, the U.S. War Department requested information about Italian American servicemen from their commanding officers and then presented a list of the naturalized and alien Italian soldiers in the U.S. Army to the Italian government for exemption from military service in Italy. ${ }^{80}$

For the United States and Italy, World War I completed a military restructuring that reflected the two countries' ambition for national consolidation through the projection of power. The renovation of the U.S. Army and Navy begun in the late nineteenth century accelerated, and the United States began to project its strength with large armed forces not only in the western hemisphere, but all around the world. Meanwhile, the United States showed determination to protect the rights of its citizens regardless of their ethnic origins or physical location. Likewise, whereas the Italian Army's responsibility had historically been limited to peninsular concerns, now the Kingdom of Italy's craving for colonies and Italy's entrance into the Great War required the mobilization of nearly five-million Italians for action

${ }^{78}$ Ambassador Page to the Secretary of State, Aug. 4, 1915, FRUS, 1915, 573.

${ }^{79}$ Chief of Bureau of Citizenship R. W. Flournoy, Jr., to the Secretary of State, FRUS, $1915,581$.

${ }^{80}$ For details, see Ford, Americans All!, 128. 
around the Mediterranean. Remote emigration of Italian subjects came to seem unhelpful to such a regime in pursuit of great power status.

Thus U.S. officials zealously defended their naturalized citizens on the basis of jus soli-even though these same immigrants were often subjected to ethnic discrimination and even violence in the United States. In the meantime, Italy maintained its policy of jus sanguinis throughout the period, a reflection both of evolving government aspirations and the necessities of Old World military readiness. The United States and Italy passed through the early 1900 s with simmering disagreements about their policies with reference to the concepts of citizenship and military service in both countries.

The potential crisis between the United States and the Kingdom of Italy about military service came to an end, however, in 1918 when the United States signed treaties with its European allies, including Italy, after a series of military-service conventions. The reciprocal military-service agreement between Italy and the United States was signed in Washington, on August 24,1918 . With this treaty, both countries stated that Italian citizens in the United States and American citizens in Italy could either go back to their native country for military service or serve in the armed forces of the country in which they resided for the better prosecution of the war. ${ }^{81}$ Additionally, the agreement proscribed the loss of nationality of men who served in the other country's army. The 1918 military-service treaties effectively established a kind of Atlantic citizenship for men of Allied nations, though that citizenship carried the risk of discrimination in some circumstances, not to mention death or injury in wartime service. Italian mass migration exerted pressure on the Italian government to liberalize its military conscription laws and led the American government to grant a nonNorthern European immigrant group the protection of U.S. federal law. Italian migration thus effectively enhanced both governments' capacity to wage war as well as each country's international status as great powers.

Perhaps surprisingly, the Fascist government of Benito Mussolini did not resume the old practice of seizing American citizens of Italian extraction for military service when traveling in Italy. 82 The 1918 treaty remained in effect until December 1941, when Italy declared war on the United States. After World War II, occasional cases arose over the resumed Italian enforcement of military conscription. Article 52 of the 1948 Constitution of Italy affirmed compulsory military service. In 1966, a case arose concerning the

${ }^{81}$ Washington and Rome exchanged ratifications on November 14, 1918; see Treaty Series No. 637, "Convention Between the United States and Italy Providing for Reciprocal Military Service, Signed at Washington, August 24, 1918," FRUS, 1918, Supplement 2, The World War, 726.

${ }^{82}$ See Marcus Duffield, "Mussolini's Red Herring," The Nation, Nov. 27, 1929, 644.

${ }^{83}$ Alona E. Evans, "Cafiero v. Kennedy, 262 F. Supp. 140," American Journal of International Law 61 (July 1967): 815. 
376 Journal of the Gilded Age and Progressive Era / July 2008

military service of a naturalized American citizen born in Italy in 1932 . He was called for military service and served in the Italian Army for two years. In the end, the man lost his American nationality since, according to the U.S. courts, he had voluntarily joined the Italian Navy. ${ }^{83}$ The practice of mandatory military service in Italy remained until May 8, 2001, when the Italian Parliament enacted a new law making military service voluntary. According to this statute, Italian male citizens born between 1976 and December 31, 1985 , were obliged to perform military services, but the obligation ceased for men born after January 1, 1986. Thus, for the time being at least, the possibility of clashes between Italy and the United States over Italian conscription of naturalized Americans has disappeared. 